\title{
"Status quo" w podejmowaniu decyzji finansowych
}

\author{
Status quo bias in financial decision making
}

\section{Wprowadzenie}

Od początku rozwoju ekonomii jako dziedziny nauki wiele poruszanych problemów ekonomicznych wymagało interdyscyplinarnego podejścia, tak aby w pełni zrozumieć badane procesy ekonomiczne, ich podłoże oraz skutki.

Jednym z przykładów istotnie ważnego współdziałania ekonomii z innymi dziedzinami jest badanie ludzkich zachowań. Mimo że decyzje ludzi są nierozerwalną częścią procesów ekonomicznych, nie można ich analizować jedynie w odniesieniu do teorii ekonomii. Pojawienie się nowego modelu człowieka jako postaci nieracjonalnej, ulegającej emocjom, przyzwyczajeniom oraz subiektywnym odczuciom wskazuje na konieczność połączenia teorii ekonomii oraz psychologii, czasem również socjologii czy nawet genetyki.

Odpowiedzią na te wymagania stawiane nauce stała się ekonomia behawioralna jako próba zrozumienia wpływu czynników psychologicznych na ludzkie zachowania i wybory. Jednym z mechanizmów psychologicznych jest efekt status quo, który odgrywa istotną rolę w podejmowaniu decyzji, również ekonomicznych. Na podstawie badań starano się udowodnić, że zachowania ludzi cechują się nieświadomym kontynuowaniem wcześniej podjętych decyzji, a także konsekwentnym trwaniem w zastanej sytuacji, pomimo często całkowitej nieracjonalności takiego postępowania.

Efekt status quo był badany przez wielu naukowców. Skupiano się przy tym zwłaszcza na sile jego oddziaływania. W pracach, które omawiały problem status 
quo, można napotkać również hipotezy dotyczące wpływu czasu trwania danej sytuacji na jej odbiór przez badanych.

Celem badania opisanego w artykule była weryfikacja mniejszej skłonności do zmian u badanych, którzy zostali poddani ramowaniu niż u osób, które nie miały przedstawionej sytuacji wyjściowej. Niniejsza hipoteza została zaczerpnięta z artykułu Williama Samuelsona i Richarda J. Zeckhausera z 1988 r. Artykuły Scotta Eidelmana posłużyły za podłoże do modyfikacji wspomnianego założenia poprzez wprowadzenie czynnika czasu. Zabieg ten miał za zadanie zbadanie, w jaki sposób wpłynie on na siłę oddziaływania efektu podczas podejmowania decyzji ekonomicznych, ponieważ do tej pory przeprowadzone badania skupiały się głównie na jego wpływie w odniesieniu do problemów czysto socjologicznych, jak aprobata tortur podczas przesłuchań świadków czy też ocena efektywności akupunktury. Zgodnie z założeniami Eidelmana badani, którzy byli świadomi dłuższego czasu trwania danej sytuacji (20 lat), powinni być bardziej niechętni do jej zmiany, niż miałoby to miejsce w przypadku krótszego okresu (3 miesiące).

W pierwszej części artykułu dokonano przeglądu literatury podejmującej tematykę status quo. Następnie przedstawiono problem i cel badania własnego oraz zastosowaną metodę badawczą. Badanie przeprowadzono metodą CAWI w formie ankiety zamieszczonej na portalu społecznościowym. Następnie dokonano analizy otrzymanych wyników w odniesieniu do założonych hipotez z zastosowaniem jednoczynnikowej analizy wariancji (ANOVA). Artykuł zakończono dyskusją wyników oraz wskazaniem możliwych przyczyn braku potwierdzenia całości zakładanych hipotez.

\section{1. „Status quo” jako obszar badań naukowych}

Literatura dotycząca problematyki efektu status quo jest bogata i porusza wiele aspektów tego zagadnienia (por. Kahneman, Tversky, 1982, s. 160-173; Kahneman, Slovic, Tversky, 1982; Simonson, 1992, s. 105-118; Zeelenberg, 1999, s. 93-106; Kay, 2009, s. 421-434; Tyszka, 2004; Belsky, Gilovich, 2010).

Madrian i Shea (2001, s. 1149-1187) w badaniach wskazują na istniejące różnice w podejściu poszczególnych jednostek do zmian (skłonność do zmiany). Autorzy zwracają jednak uwagę na dominującą wśród badanych postawę niechęci do zmiany status quo, czyli bieżącego stanu, bez względu na to, czy był on wynikiem ich aktywności czy jej braku. Badania ukazują zarówno pozytywne, jak i negatywne oddziaływanie efektu status quo na podejmowanie decyzji. Nie ulega wątpliwości, że wzrost uczestnictwa pracowników w funduszu emerytalnym jest dla nich ko- 
rzyścią, a więc decyzją świadczącą o racjonalności. Jednak spadek udziału akcji lub obligacji w portfelach inwestycyjnych, co wskazuje na zwiększoną, a nawet nadmierną ostrożność, może być odbierany negatywnie. W odniesieniu do długiej perspektywy czasowej to inwestowanie w bardziej ryzykowne instrumenty finansowe, jak w tym przypadku akcje i obligacje, okazuje się bardziej opłacalne niż lokowanie kapitału w bony skarbowe (Reilly, Brown, 2001).

Z kolei o czynnikach wpływających na przyjęcie postawy niechętnej zmianom pisał Tyszka (2010, s. 268-269). Szczególną uwagę zwrócił na lęk przed nieznanym, który mógł uniemożliwiać racjonalne oszacowanie prawdopodobieństwa pojawienia się pozytywnych skutków podejmowanych działań. Wspomniany autor wyróżnił również powody przezwyciężania niechęci do zmian, tj. poszukiwanie różnorodności oraz dążenie do perfekcjonizmu. Badania przeprowadzone przez Samuelsona i Zeckhausera udowodniają, że awersja do zmian może być także silniejsza niż osobiste preferencje (Samuelson, Zeckhauser, 1988, s. 7-59).

Tak jak zostało to wspomniane przy badaniu wykonywanym przez Madriana i Sheę oraz na podstawie kolejnych przykładów potwierdzających obecność status quo w podejmowaniu decyzji, efekt ten może mieć pozytywne i negatywne konsekwencje.

Można wyróżnić czynniki, które sprzyjają powstawaniu oraz podtrzymują status quo. Uzasadnione jest $\mathrm{w}$ tym przypadku podzielenie ich na dwie grupy: racjonalne oraz nieracjonalne.

\subsection{Racjonalne wyttumaczenia zachowywania „status quo”}

Występuje kilka różnych powodów, żeby utrzymywać już istniejące stany. W sytuacji, gdy pewna decyzja została wcześniej podjęta, a nie nastąpiła zmiana w preferencjach oraz zestawie alternatywnych rozwiązań, nieracjonalne wydaje się odrzucenie status quo. Wynika to z wcześniej wspomnianych kosztów transakcyjnych, które mogą być na tyle dużym obciążeniem, że zmiana sytuacji nie będzie korzystna (Eidelman, Crandall, 2012, s. 270-281).

W związku z trudem dokonywania decyzji decydenci są bardziej skłonni do bezczynności (Ritoy, Baron, 1990, s. 263-277) lub podejmowania takich samych akcji, jak robili to wcześniej (Samuelson, Zeckhauser, 1988, s. 7-59), co oznacza, że koszty poznawcze przeważają nad korzyściami płynącymi z przyjęcia innego wariantu zachowania. Jako dowód mogą służyć badania, w których wykazano, że decydenci są bardziej skłonni do odkładania decyzji w czasie, jeśli pojawiają się alternatywy zachowań (Tversky, Shafir, 1992, s. 358-361), a także siła efektu status quo wzrasta wraz ze wzrostem liczby dostępnych opcji (Samuelson, Zeckhauser, 
1988, s. 7-59). Podsumowując, zachowanie status quo wymaga mniejszego zaangażowania poznawczego i psychicznego (Eidelman, Crandall, 2009, s. 85-106).

Oprócz ograniczeń poznawczych istnieją również wywołane przez konieczność decydowania ograniczenia informacyjne. Wyniki podjętych decyzji bardzo rzadko są pewne, tak samo jak ich użyteczność. $Z$ racji tego, że niektóre błędy są kosztowniejsze od innych (Friedrich, 1993, s. 298-319), tkwienie w tym, co zostało wypracowane w przeszłości, jest bezpieczną opcją, która sprawia, że status quo jest mądrym wyborem. Tak długo jak poprzednie decyzje są wystarczająco dobre dla decydenta (Simon, 1956, s. 129-138), przejawia on awersję do zmian, a tym samym oszczędza własną energię, która byłaby potrzebna do przetwarzania nowych informacji. Ze względu na zmienność oraz niepewność otaczającego świata osiągnięcie wystarczającej satysfakcji wydaje się rozsądniejszą decyzją niż poszukiwanie jak największej użyteczności (Schwartz, Ben-Haim, Dacso, 2011, s. 209-277).

\subsection{Nieracjonalne wyttumaczenia zachowywania „status quo"}

Oba wspomniane we wcześniejszej części efekty: skłonność do bezczynności oraz zachowywanie status quo są oparte na występowaniu awersji do strat oraz unikaniu żalu (Kahneman, Knetsch, Thaler, 1991, s. 193-206). W wyniku traktowania stanu istniejącego jako punkt odniesienia dla oceny efektów decyzji koszty zmiany będą postrzegane jako ważniejsze niż potencjalne zyski (Moshinsky, Bar-Hillel, 2010, s. 191-204). Dana niechęć ponoszenia strat prowadzi również do faworyzowania bezczynności, która prowadzi do mniejszego żalu w przypadku niepowodzenia (Kahneman, Tversky, 1982, s. 201-210). Wymienione efekty doprowadzają do przypisywania wierności status quo dużej atrakcyjności bez racjonalnego potwierdzenia, przez co zmiany są unikane, a decydenci tkwią w postanowieniach podjętych w przeszłości (Samuelson, Zeckhauser, 1988, s. 7-59).

W rozważaniach nad efektami, które podtrzymują status quo, jest ważne dostrzeżenie dużej roli tzw. a bias for existence. Zjawisko to polega na faworyzowaniu stanów istniejących, ponieważ ich byt jest przesłanką, aby sądzić o ich pozytywnych właściwościach (Eidelman, Crandall, 2009, s. 270-281). Wyobrażenie wyniku powoduje, że staje się on bardziej prawdopodobny (Anderson, 1983, s. 293-305).

Kolejnym czynnikiem, który wpływa na postrzeganie atrakcyjności alternatywnych opcji podejmowanej decyzji, jest czas trwania istniejącego stanu. Badania dowiodły, że ankietowani, którzy byli informowani o relatywnie długim okresie występowania danego zjawiska, oceniają je pozytywniej i dostrzegają 
ważne przesłanki, aby je kontynuować. Osoby, którym został przedstawiony krótszy okres, są surowsze w swojej ocenie i bardziej skłonne do podjęcia zmian (Eidelman, Patterhal, Crandall, 2010, s. 993-998; Crandall, Eidelman, Skitka, Morgan, 2009, s. 1-10).

\section{Problem i cel badania}

Podejmowanie decyzji jest złożonym procesem, na który wpływa wiele czynników. Często pod ich wpływem następuje zachwianie racjonalności zachowania człowieka. Jednym z tych czynników jest skłonność do trzymania się wcześniejszych postanowień. Powodowana jest ona silną awersją przed ryzykiem, które jest dostrzegane w nowych i nieznanych sytuacjach. Prostszym kierunkiem postępowania jest powielanie znajomych schematów. Inną z przyczyn niechęci do zmian jest unikanie wysiłku związanego z podjęciem działania zamiast tkwienia w stagnacji.

Jednym z efektów unikania zmian jest podtrzymywanie status quo, czyli tendencja do utrzymywania istniejącego stanu rzeczy oraz powielania wcześniejszych decyzji. Celem badania jest potwierdzenie powszechności występowania efektu status quo oraz wskazanie wpływu długości trwania danej sytuacji na podejmowane decyzje.

Głównym problemem badawczym było zbadanie, czy ankietowani, którzy zostali poinformowani o istniejącym stanie rzeczy, byli bardziej skłonni do jego podtrzymania, niż osoby, które takiej świadomości nie miały. Co więcej, narzucenie dłuższego czasu trwania sytuacji (20 lat) powinno powodować, że badani będą wykazywać się wyższą awersją do zmian w porównaniu z odpowiedziami badanych z grupy o krótszym okresie (3 miesiące).

\subsection{Metodyka badania}

Badania zostały przeprowadzone drogą internetową $\mathrm{w}$ formie anonimowej ankiety zamieszczonej na grupach społecznościowych na portalu Facebook (metoda CAWI) w dniach 17-25 maja 2017 r. Dzięki zastosowanej metodzie badawczej ankietowani mogli podjąć szybką i intuicyjną decyzję bez udziału i sugestii ankietera. Próba badawcza wyniosła 181 osób, przy czym kobiety stanowiły 76\% wszystkich ankietowanych. W tabeli 1 zawarto wspomniane dane dla obu płci. 64\% badanych posiadało średnie wykształcenie, a 33\% - wyższe. Wśród ankietowanych dominowały osoby młodsze, gdyż $90 \%$ próby badawczej to osoby do 25 roku życia. 
72 | Przegląd Prawno-Ekonomiczny

Tabela 1. Udział kobiet i mężczyzn w całkowitej liczbie badanych

\begin{tabular}{|l|c|c|}
\hline \multicolumn{1}{|c|}{ Płeć } & Liczba & Udział procentowy \\
\hline Kobiety & 138 & 76 \\
\hline Mężczyźni & 43 & 24 \\
\hline Ogółem & 181 & 100 \\
\hline
\end{tabular}

Źródło: opracowanie własne.

Zostały przygotowane 4 zestawy składające się z 3 sytuacji, do których ankietowani musieli się ustosunkować poprzez wybranie jednej z 4 zaproponowanych opcji. Problemy pochodziły z artykułu Samuelsona oraz Zeckhausera z 1988 r. i po przetłumaczeniu na język polski stanowiły dwie z czterech wersji (wersja neutralna oraz wersja ze status quo). Pozostałe dwie wersje były modyfikacją sytuacji ze status quo i wprowadzały w treść problemów okres występowania danej sytuacji problemowej. Były to 3 miesiące oraz 20 lat. Takie okresy czasowe zostały wybrane na podstawie przeprowadzonego wcześniej badania pilotażowego.

\section{Wyniki badania}

Do opracowania wyników zastosowano wskaźnik, który dzięki przypisaniu do każdej odpowiedzi zgodnej z hipotezami wartości 1 (analogicznie odpowiedzi niezgodnej nadano wartość 0) oraz obliczeniu średniej wartości wskaźnika dla wszystkich przebadanych, pozwalał określić, w jakim stopniu dana osoba uległa zakładanym heurystykom. Zatem w wersji neutralnej oraz w wersjach ramowanych przyjęto odpowiedzi z podpunktu a) jako zgodne $z$ hipotezami. Minimalny poziom wskaźnika dla jednej osoby wynosił 0 i świadczył on o zupełnie odmiennych odpowiedziach ankietowanego niż były zakładane, czyli ankietowany nie uległ efektowi status quo. Natomiast maksymalny poziom wskaźnika mógł wynieść 3 dla każdego badanego i świadczył o całkowitej niechęci do zmiany sytuacji wyjściowej. W tabeli 2 zostały zaprezentowane dane dotyczące przeciętnych poziomów wskaźników wraz z odchyleniami standardowymi w grupach reprezentujących poszczególne zestawy pytań. 
Tabela 2. Średnie poziomy wskaźników wraz z odchyleniem standardowym dla grup

\begin{tabular}{|c|c|c|c|}
\hline 1. Neutralna $(\mathrm{N}=53)$ & $\begin{array}{c}\text { 2. Ze status quo } \\
(\mathrm{N}=53)\end{array}$ & $\begin{array}{c}\text { 3. Ze status quo (3 } \\
\text { miesiące) }(\mathrm{N}=36)\end{array}$ & $\begin{array}{c}\text { 4. Ze status quo }(20 \\
\text { lat) }(\mathrm{N}=39)\end{array}$ \\
\hline $1,019(0,82)$ & $1,377(0,79)$ & $1,528(0,81)$ & $1,128(0,823)$ \\
\hline
\end{tabular}

Źródło: opracowanie własne.

Średni poziom wskaźnika w grupach nie odzwierciedla jednak wewnętrznego zróżnicowania odpowiedzi na poszczególne zadania. Dzięki dalszej analizie otrzymanych danych zaobserwowano, że jedynie w odniesieniu do zadania pierwszego najczęściej wybierana opcja była niezgodna z założonymi hipotezami.

$\mathrm{W}$ wyniku porównania grup, przedstawionych $\mathrm{w}$ tabeli 2 , uzyskano istotności tych wartości (tabela 4). Zastosowano przy tym następujące oznaczenia:

1 - oznacza grupę neutralną,

2 - oznacza grupę ze status quo,

3 - oznacza grupę ze status quo (3 miesiące),

4 - oznacza grupę ze status quo (20 lat).

W tabeli 3 zostały zaprezentowane dane dotyczące wartości $p$ dla porównań wyników wskaźnika dla płci oraz interakcji dla płci oraz warunku, tj. poszczególnych grup. W wyniku przeprowadzenia jednoczynnikowej analizy wariancji uzyskano wartości $p$ niższe niż 0,05 dla dwóch czynników, co oznacza, że mają one wpływ na zmienną zależną, jaką jest poziom wskaźnika.

Tabela 3. Porównania średnich dla grupy oraz płci

\begin{tabular}{|l|c|c|}
\hline \multicolumn{1}{|c|}{ Źródło } & F & Wartość p \\
\hline Warunek & 4,849 & 0,003 \\
\hline Płeć & 9,301 & 0,003 \\
\hline Warunek $^{*}$ płeć & 0,643 & 0,588 \\
\hline
\end{tabular}

Źródło: opracowanie własne.

W wyniku kolejnych porównań zmienna międzyobiektowa, tj. prezentowany badanym warunek (wersja neutralna, wersja ze status quo, wersja ze status quo - 3 miesiące, wersja ze status quo - 20 lat), okazała się istotna statystycznie, $\mathrm{F}(3,173)=4,849 ; \mathrm{p}=0,003$. Zatem analiza wykazała, że między niektórymi grupami występują statystycznie istotne różnice. Potwierdza to porównania dla poszczególnych par zaprezentowane w tabeli 4, które wymagały zastosowania testu post-hoc. Zawarte w tabeli poziomy istotności zostały uzyskane w wyniku przeprowadzenia testu Bonferroniego. 
Na podstawie analizy wariancji (tabela 3), istotne statystycznie są również porównania dla płci, które zostały zestawione w tabeli 5, F $(1,173)=9,301$; $\mathrm{p}=0,003$. Jednak interakcja dla płci oraz warunku nie odnalazła potwierdzenia i okazała się nieistotna, $\mathrm{F}(3,173)=0,643 ; \mathrm{p}=0,588$.

Tabela 4. Wartość p dla porównań parami pomiędzy grupami ogółem

\begin{tabular}{|c|c|c|c|c|c|}
\hline $1-2$ & $1-3$ & $1-4$ & $2-3$ & $2-4$ & $3-4$ \\
\hline 0,055 & 0,004 & 0,999 & 0,999 & 0,603 & 0,071 \\
\hline
\end{tabular}

Źródło: opracowanie własne.

Istotne statystycznie okazało się porównanie średniego poziomu wskaźników wersji neutralnej z wersją status quo - 3 miesiące (1-3). Wyniki pokazują zatem, że w przypadku wersji ramowanej badani częściej wybierają opcję domyślną. Podobną zależność można zaobserwować, przy porównaniu wersji ze status quo z wersją neutralną (1-2) oraz porównaniu wersji ze status quo - 3 miesiące z wersją status quo - 20 lat (3-4), chociaż istotności porównań ww. par są jedynie na poziomie tendencji statystycznej. Przyglądając się średnim poziomom wskaźnika dla każdej z grup, najwięcej odpowiedzi zgodnych z zakładanymi odnotowano w wersji status quo - 3miesiące, następnie dla wersji ze status quo, wersji ze status quo - 20 lat oraz wersji neutralnej. Taka analiza potwierdza skuteczność zastosowanej w badaniu manipulacji.

Z racji małego zróżnicowania wiekowego (badania przeprowadzone zostały głównie wśród studentów), starano się odnaleźć ważne powiązania i zależności uzyskanych wyników z innymi czynnikami. W wyniku analizy danych (tabela 3), zauważono różnice w wynikach dla kobiet oraz mężczyzn, które przedstawiono w tabeli 5 .

Tabela 5. Poziom wskaźnika odpowiedzi w odniesieniu do płci oraz liczba obserwacji

\begin{tabular}{|l|c|c|}
\hline \multicolumn{1}{|c|}{ Płeć } & $\begin{array}{c}\text { Średni wynik wskaźnika } \\
\text { w grupie }\end{array}$ & Liczba obserwacji \\
\hline Kobieta & 1,357 & 138 \\
\hline Mężczyzna & 0,922 & 43 \\
\hline
\end{tabular}

Źródło: opracowanie własne. 


\section{Dyskusja wyników i kierunki dalszych badań}

Dokonując podstawowej analizy otrzymanych wyników, trzeba zauważyć, że powyższe dane wykazują się istotnością i po części założona hipoteza o silniejszym oddziaływaniu czasu na intensywność występowania status quo znalazła potwierdzenie w omawianych danych.

Średnie wskaźników zamieszczonych w tabeli 2 nie wykazują zależności przedstawionych przez Eidelmana, które były podstawą do budowy omawianego badania. Zgodnie z założoną hipotezą wskaźniki kolejnych grup powinny wzrastać, jednak jak wskazano w analizie, badani byli najbardziej skłonni do ulegania status quo w grupach z narzuconym czasem trwania sytuacji równym 3 miesiącom. W odniesieniu do hipotez można stwierdzić, że ta nie została potwierdzona, gdyż porównanie z wersją ze status quo - 20 lat nie spełnia oczekiwań.

Zauważono statystycznie istotną zależność między grupami 1 i 3, co mogłoby potwierdzić założone hipotezy o uleganiu status quo, jednak kolejny wynik grup 3 i 4 przeczy wpływowi czasu na podatność na heurystykę. Niniejsze wnioski potwierdzają zatem występowanie skuteczności manipulacji, gdyż wersja neutralna odnotowała najniższy wynik z każdej z grup.

Uzyskane wyniki mogą być natomiast podłożem do kontynuacji badań nad wpływem czasu w obrębie zagadnień finansowych ze względu na małą popularność tego efektu wśród naukowców, a jednocześnie jego duży potencjał. Jedną z modyfikacji badania mogłaby być zmiana podanych okresów trwania przykładowych sytuacji. W przypadku badania, na którym opiera się praca, zastosowano przedziały 3 miesiący oraz 20 lat, ponieważ w rezultacie pilotażu te dwie opcje uzyskały najbardziej skrajne wyniki. Taki dobór wartości miał na celu większe prawdopodobieństwo wystąpienia różnic w odpowiedziach ankietowanych i uwypuklenie efektu.

Warto również zwrócić uwagę na zawarte w tabeli 4 poziomy istotności porównań między grupami 1-2 oraz 3-4. Uzyskane wyniki mogą sugerować, że większa próba badawcza wpłynęłaby pozytywnie na poziom istotności i wspomniane porównania zyskałyby cenny potencjał badawczy.

W omawianym badaniu wykorzystano zadania zaczerpnięte z artykułu Samuelsona oraz Zeckhausera, jednak jak wykazała analiza danych, ankietowani w odmienny sposób reagowali na zaprezentowane im poszczególne sytuacje. Opcja zgodna z hipotezami nie była najczęściej wybieraną odpowiedzią w zadaniu pierwszym w żadnej z grup, co mogło przełożyć się na średni poziom wskaźnika 
dla całej grupy. Planując kolejne badania, warto rozważyć uwzględnienie innych sytuacji w formularzu ankiety.

Podczas analizy zauważono jednak również istotny czynnik, który stanowi dodatkowy powód do zwiększenia zainteresowania tym zagadnieniem, tj. wpływ płci na podejmowane decyzje. Jak wynika $z$ danych tabeli 5 , kobiety w większym stopniu ulegały heurystykom, a ich wybory odznaczały się wyższym poziomem awersji do ryzyka niż występowało to u mężczyzn.

Biorąc pod uwagę przytoczoną zależność, można wywnioskować, że tak wysoki udział kobiet w ogóle badanych nie pozostał bez znaczenia dla całego wyniku badania. Zachowanie kobiet jest nacechowane ostrożnością, co zostało potwierdzone przez wielu naukowców, i może znacząco wypaczyć rezultat analizy (Tyszka, Domurat, 2004, s. 85-104).

Różnice między skłonnością do zmian i podejmowania ryzyka u kobiet i mężczyzn są ważnym zjawiskiem w procesie podejmowania decyzji finansowych. Odpowiedni dobór słów, przedstawienie sytuacji (bądź oferty, jeśli weźmie się pod uwagę konstruowanie strategii marketingowych) może zadziałać na obie płcie, jednak odnalezienie wspólnego czynnika wymaga podjęcia kolejnych badań.

Przewaga kobiet wśród ankietowanych nie musi tłumaczyć braku potwierdzenia całości zakładanych hipotez, ale może być jednym z czynników, które na to wpłynęły. Planując kolejne badania, warto wziąć pod uwagę porównanie odpowiedzi grup osób różniących się poziomem wykształcenia, znajomością wiedzy ekonomicznej czy też wiekiem.

Mimo poruszania tematu czynników wpływających na status quo głównie na płaszczyźnie problemów socjologicznych, trzeba zauważyć, że to właśnie w procesie podejmowania decyzji finansowych ryzyko, z którym nierozerwanie związany jest status quo, odgrywa znaczącą rolę i tylko dokładne poznanie tego efektu może doprowadzić do lepszego zrozumienia ekonomicznych procesów decyzyjnych wśród ludzi.

\section{Podsumowanie}

Przeprowadzone badania w pewnym stopniu potwierdziły tezę o istnieniu efektu status quo, jednak nie wykazały jednoznacznych zależności, jeśli wziąć pod uwagę wersje zmodyfikowane pod wpływem czasu.

Chociaż badania zostały skonstruowane na podstawie sprawdzonego i często powtarzanego modelu zaprezentowanego przez Samuelsona i Zeckhausera, nie sprawdziły się one tak jak zaprezentowano to w ich artykule. Mogą przemawiać za 
tym różne czynniki, które jednocześnie stanowią istotne wskazówki dla badaczy, którzy zainteresują się tą tematyką.

Warte kolejnego potwierdzenia oraz dogłębnego przeanalizowania jest pojawienie się czynnika płci jako determinującego wynik ulegania status quo. Istotne wydaje się również zastosowanie bardziej zróżnicowanej grupy badawczej, ponieważ omawiane badanie było przeprowadzone głównie na ludziach młodych, którzy wykazują się specyficznymi cechami charakteru, jak chęci zmian czy gotowość do ryzykowania (Czauderna, 2016, s. 35-36). Jest to prawdopodobne, że inny dobór grupy badawczej przy jednoczesnym zwiększeniu jej wielkości skutkowałby innymi wynikami i spotęgowaniem efektu status quo wśród badanych.

Istnieje wiele możliwości zmodyfikowania całej procedury badania poprzez zastosowanie skali atrakcyjności opcji dla każdego badanego. Takie rozwiązanie powinno wykazać się większą czułością w otrzymanych wynikach i łatwiejszym odnalezieniu tendencji w zachowaniach ludzi. Zmianie mogą ulec również zaproponowane $\mathrm{w}$ niniejszej pracy okresy trwania sytuacji, tj. 3 miesiące oraz 20 lat. Zostały one wybrane na drodze badania pilotażowego, jednak nie ulega wątpliwości, że nie są one jedynym słusznym wyborem i możliwy jest trafniejszy dobór, który pozytywnie wpłynie na potwierdzenie tezy.

Ostatecznie, trudno oszacować, czy ten sam mechanizm wpływu czasu, który zadziałał wzmacniająco w badaniu Eidelmana, odnajdzie swoje potwierdzenie na gruncie decyzji ekonomicznych, które cechują się swoistą specyfiką i poprzez silne odczuwane emocje związane z wynikami danych zachowań mogą różnić się od decyzji socjologicznych. Analiza zawarta w niniejszej pracy nie potwierdziła istotnie ważnej zależności, a co za tym idzie, może sugerować, że różnice między postrzeganiem decyzji ekonomicznych i socjologicznych są na tyle duże, iż nie będą miały takiego samego wpływu na badanych.

Podsumowując, pomimo jedynie częściowego potwierdzenia postawionych hipotez, temat istnienia status quo jest bardzo atrakcyjny i pełen możliwości do kontynuowania badań. Istnieje wiele sposobów modyfikacji i szukania zależności między postawieniem problemu przed badanym a jego zachowaniem. W związku z powszechną obecnością tego efektu wśród społeczeństwa badania nad nim nabierają wartości, ponieważ uzyskane wnioski mogą okazać się przydatne w różnych sferach rynku, np. podczas konstruowania strategii marketingowych.

\section{Bibliografia}

Anderson, C. A. (1983). Imagination and expectation: The effect of imagining behavioral scripts on personal intentions. Journal of Personality and Social Psychology, 45, 293-305. 
Belsky, G., Gilovich, T. (2010). Why Smart People Make Big Money Mistakes. New York: Simon \& Schuster.

Crandall, C. S., Eidelman, S., Skitka, L., Morgan, G. S. (2009). Status quo framing increases support for torture. Social Influence, 4, 1-10.

Czauderna, K. (2016). Paradoksy skłonności do ryzyka. O pewnej nieścisłości teorii perspektywy. Wiadomości Statystyczne. The Polish Statistician, 2, 25-46.

Eidelman, S., Crandall, C. (2009). On the psychological advantage of the status quo. W: J. Jost, A. Kay, H. Thorisdottir (Eds.), Social and Psychological Bases of Ideology and System Justification (s. 85-106). New York: Oxford University Press.

Eidelman, S., Crandall, C. (2012). Bias in Favor the Status Quo. Social and Personality Psychology Compas, 6(3), 270-281.

Eidelman, S., Patterhal, J., Crandall, C.S. (2010). Longer is better. Journal of Experimental Social Psychology, 46, 993-998.

Friedrich, J. (1993) Primary error detection and minimization (PEDMIN) strategies in social cognition: A reinterpretation of the confirmation bias phenomenon. Psychological Review, 100, 298-319.

Kahneman, D., Knetsch, J., Thaler, R. (1991). The endownment effect, loss aversion, and status-quo bias. Journal of Economics Perspectives, 5, 193-206.

Kahneman, D., Tversky, A. (1982). The simulation heuristic. W: D. Kahneman, P. Slovic, A. Tversky (Eds.), Judgment Under Uncertainty: Heuristics and Biases (s. 2012010). New York: Cambridge University Press.

Kahneman, D., Slovic, P., Tversky, A. (1982). Judgment Under Uncertainty: Heuristics and Biases. New York: Cambridge University Press.

Kay, A. (2009). Inequality, discrimination, and the power of the status quo: Direct evidence for a motivation to see the way things are as the way they should be. Journal of Personality and Social Psychology, 97, 421-434.

Madrian, B., Shea, D. (2001). The power of suggestion: Inertia in 401(k) participation and savings behavior. Quarterly Journal of Economics, 116, 1149-1187.

Moshinsky, A., Bar-Hillel, M. (2010). Loss aversion and status quo label bias. Social Cognition, 28, 191-204.

Reilly, F., Brown, K. (2001). Analiza inwestycji i zarządzanie portfelem. Warszawa: Polskie Wydawnictwo Ekonomiczne.

Ritov, I., Baron, J. (1990). Reluctance to vaccinate: Omission bias and ambiguity. Journal of Behavioral Decision Making, 3, 263-277.

Samuelson, W., Zeckhauser, R. (1988). Status quo bias in decision making. Journal of Risk and Uncertainty, 1, 7-59. 
Schwartz, B., Ben-Haim, Y., Dacso, C. (2011). What makes a good decision? Robust satisficing as a normative standard of rational decision making. Journal for the Theory of Social Behaviour, 41, 209-277.

Simon, H. (1956). Rational choice and the structure of the environment. Psychological Review, 63, 129-138.

Simonson, I. (1992). The influence of anticiapting regret and responsibility on purchase decisions. Journal of Consumer Research, 19, 105-118.

Tversky, A., Shafir, E. (1992). Choice under conflict: The dynamics of deferred decision. Psychological Science, 3, 358-361.

Tyszka, T. (red.). (2004). Psychologia Ekonomiczna. Gdańsk: Gdańskie Wydawnictwo Psychologiczne.

Tyszka, T. (2010). Decyzje. Perspektywa psychologiczna i ekonomiczna. Warszawa: Wydawnictwo Naukowe SCHOLAR.

Tyszka, T., Domurat, A. (2004). Czy istnieje ogólna skłonność jednostki do ryzyka? Decyzje, 2, 85-104.

Zeelenberg, M. (1999). Anticipated regret, expected feedback and behavioral decision making. Journal of Behavioral Decision Making, 12, 93-106.

\section{Streszczenie}

Status quo jest ważnym efektem występującym w procesie podejmowania decyzji. Badacze określają w ten sposób nieświadome podtrzymywanie stanu bieżącego i niechęć do zmian. W niniejszym artykule w wyniku badania założone hipotezy nie zostały całkowicie potwierdzone. Zauważono statystycznie istotną zależność między grupą neutralną a grupą, w której status quo występował przez 3 miesiące, co mogłoby potwierdzić założone hipotezy o uleganiu temu efektowi. Kolejny wynik grup ze status quo - 3 miesiące oraz status quo - 20 lat przeczy wpływowi czasu na podatność na heurystykę. Rezultaty badania mogą wynikać z czynników, które jednocześnie stanowią istotne wskazówki dla badaczy zainteresowanych tą tematyką.

SŁowA KLUCzowE: status quo, ekonomia behawioralna, psychologia ekonomiczna, podejmowanie decyzji.

\section{Summary}

Status quo bias is a significant effect, which is a part of the decision - making process. Researchers define status quo bias as a preference for the current state of affairs and change aversion. As a result of the research in this article, the hypotheses made, were not completely confirmed. It was alleged that there was the statistical relation between the neutral group and status quo group (3 months). It might confirm the hypothesis about the occurrence of status quo bias. The result of comparison between group status quo 
(3 months) and status quo (20 years) is a negation of susceptibility of time on heuristics. The outcomes might arise from factors, which are essential clues for researchers, who will be interested in this subject.

KEYWORDs: status quo, behavioural economics, economic psychology, decision-making process.

Małgorzata Czuchryta - mgr, absolwentka Wydziału Ekonomicznego Uniwersytetu Marii Curie-Skłodowskiej w Lublinie; główne obszary działalności naukowej: ekonomia behawioralna, polityka pieniężna, bankowość centralna; e-mail: czuchryta.malgorzatal@gmail.com; ORCID: 0000-0002-9477-268X. 